\title{
Luminance ratio at the visual tasks in classroom
}

\begin{abstract}
Possibilities of action learning methods such as interactive whiteboards, blackboards and whiteboards along with copying to a workbook depends not only on visual comfort, but also on the subjective feeling of the observer. This measurement could be performed objective was chosen as the place of visual task workbook, as the surrounding visual task desk (table) and a background visual task was elected boards according to the type of measurement rooms. Measurements was done by luxmeter and luminance analyzer. Because the evaluating the overall illuminance of the room, so the task area. Further analysis was performed luminance from which it was calculated contrast to which the eye responds and transmits the visual perception.
\end{abstract}

Keywords: ČSN EN 12464-1, luminance analysis, illuminance, luminance ratio.

\section{Introduction}

The article deals with photometric parameters in classrooms. Classrooms are unique because students regularly alternate between two places of visual tasks. The first (horizontal) area of visual tasks is a work desk with a textbook or workbook. The second (vertical) area is mostly found on the wall behind the teacher's desk and students watch the information on the whiteboard, projector, etc. illuminating, of horizontal spaces of visual tasks is in the European normative described in great detail, but the lighting of boards is described inadequately. The basic reason for this assumption is that there is no distinction, whether the classroom uses white or dark board. This article presents examples of classrooms with different lighting systems, and analysis of the light-technica parameters with an emphasis on the evaluation of the sites under consideration between visual tasks was performed. Three visual tasks were evaluated: illuminance, luminance, uniformity and reflectivity of the material. The values determined are compared within norm CSN EN 12464-1.

Tab 1 Summary of requirements according to CSN EN 12464-1 and CSN EN 73 0580-1

\begin{tabular}{|l|c|c|c|}
\hline & $\begin{array}{c}\text { Maintained } \\
\text { illuminance } \\
\mathrm{E}_{\mathrm{m}}(\mathrm{Ix})\end{array}$ & $\begin{array}{c}\text { Uniformity } \mathrm{U}_{0} \\
(-)\end{array}$ & $\begin{array}{c}\text { Recommended } \\
\text { reflectivity } \rho(-)\end{array}$ \\
\hline $\begin{array}{l}\text { Notebook } \\
\text { visual task }\end{array}$ & 300 & 0,6 & $0,75-0,8$ \\
\hline $\begin{array}{l}\text { Desk } \\
\text { araound }\end{array}$ & $200^{\star *}$ & $\mathrm{U} 0 \geq 0,1^{*}$ & $0,3-0,5$ \\
\hline $\begin{array}{l}\text { Blackboard } \\
\text { visual task }\end{array}$ & 500 & 0,7 & $\begin{array}{l}0,75-0,8 \text { (white) } \\
0,05-0,2 \text { (darkgreen) } \\
0,01-0,03 \text { (black) }\end{array}$ \\
\hline $\begin{array}{l}\text { The wall } \\
\text { around }\end{array}$ & $\mathrm{Em}>75$ & $\mathrm{U} 0 \geq 0,1^{*}$ & $0,5-0,8$ \\
\hline
\end{tabular}

* task background

** Values in Table 1 - Relationship between illuminance of immediate surroundings and illuminance at the point of the visual task norm CSN EN 12464-1

${ }^{* * *}$ Reflectance of light on common surfaces in accordance with norm CSN EN 73 0580-1

\section{Description of measurement}

For measurements were selected four classrooms with different lighting systems. Two classrooms were equipped with fitted with mounted linear fluorescent fixtures. Neither the classroom had additional lighting source. In the first there were three rows of lights, while the second had only two of them. The third classroom was equipped with two rows of mounted fluorescent luminaires with opal covers with additional lighting system with grid luminaires, which mainly provides the lighting of the classroom and not the board. In the fourth classroom is an example of what can go wrong with good intentions-quality luminaires for lighting tables and boards, but their wrong placement. Measurements were performed without daylight to evaluate only artificial illumination. Illuminance and luminance were measured with combination of visual bench seats notebook and chalkboard - wall. Monitors in the fourth computer room has been measured only by their luminance and not by illuminance, not because they act as light sources. Illuminance in the areas of visual tasks were measured as normal values for the examined sites of visual tasks. The luminance was measured using a luminance analyzer from a position above the eye of the student sitting 1.2 meters. The reflectivity of surfaces were calculated from the obtained values of illuminance and luminance with the fact that we started from the assumption that all surfaces are diffused.

For the calculation of reflectance was determined an equation:

$$
\begin{aligned}
& \text { (1) } L \cdot \pi=E \cdot \rho \Rightarrow \rho=\frac{L \cdot \pi}{E} \\
& \mathrm{~L}-\text { measured luminance }\left(\mathrm{cd} . \mathrm{m}^{-2}\right) \\
& \mathrm{E}-\text { normal illuminance }(\mathrm{Ix}) \\
& \rho-\text { reflectivity }(-)
\end{aligned}
$$

\section{Classroom 1}

In this classroom was the blackboard with a ceramic surface for which there was not any additional lighting system for creating vertical illuminance. The lighting system was relatively new (about two years), it was made of nine surface-mounted fixtures with an aluminum grid. All lamps were functional. In one luminaire were light sources of type $4 \times 36 \mathrm{~W} / 840$ 


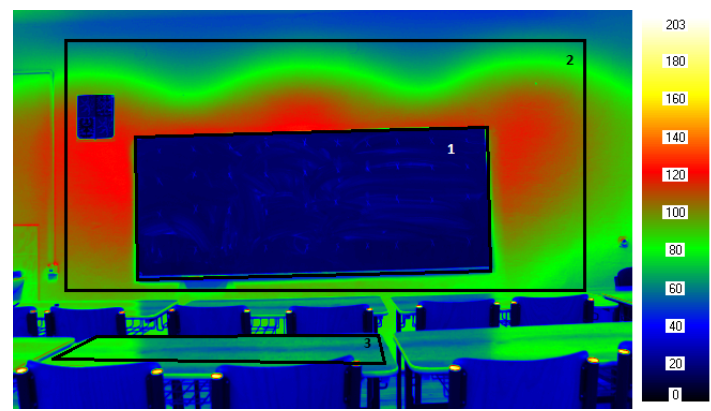

Fig.1. Classroom 1 - luminance map - representation of regions to determine the luminance

Tab 2 Measured values for classroom 1

\begin{tabular}{|l|c|c|c|c|}
\cline { 2 - 5 } \multicolumn{1}{c|}{} & $\begin{array}{c}\text { Luminance } \\
\mathrm{L}\left(\mathrm{cd} / \mathrm{m}^{2}\right)\end{array}$ & $\begin{array}{c}\text { Normal } \\
\text { illuminance } \\
\mathrm{E}(\mathrm{Ix})\end{array}$ & $\begin{array}{c}\text { Reflectivity } \\
\rho(-)\end{array}$ & $\begin{array}{c}\text { Uniformity } \\
\mathrm{U}_{0}(-)\end{array}$ \\
\hline Desk & 102,7 & 777,9 & 0,41 & 0,68 \\
\hline Blackboard & 15,5 & 453,7 & 0,11 & 0,89 \\
\hline $\begin{array}{l}\text { Paper/ } \\
\text { Notebook }\end{array}$ & 209,4 & 819,0 & 0,80 & 0,92 \\
\hline Wall & 98,5 & 413,6 & 0,75 & 0,8 \\
\hline
\end{tabular}

From luminance map in Fig. 1 shows that even when not using additional fixtures above board, the board was illuminated with fitted lights (red representation on the luminance map - Fig. 1), but the board did not reach the value of illuminance of 500 lux, which is required by the norm CSN EN 12464-1. Conversely illuminance of desks was higher than required by the standard. Standard requirement for illuminance benches and workbook (task area) is $300 \mathrm{Ix}$, and measured illuminance is $777.9 \mathrm{Ix}$. Within the sites of visual tasks we can compare two sites, paper/notebook and chalkboard. The luminance level on the blackboard was $15.5 \mathrm{~cd} . \mathrm{m}-2$ and on paper/notebook was 199,4 cd.m-2. Comparing the luminance of the workbook and the board, the value of luminance of the workbook was roughly 13 times greater than the luminance of the board. Uniformity in all evaluated sites meet the standard.

\section{Classroom 2}

As in the previous classroom, in this classroom was blackboard with ceramic surface and dark green paint. The lighting system was old (about 10 years), it consisted of 6 surface-mounted lights with aluminum grid, without additional lighting fixtures for board lighting. Lamps were distributed in two rows of three lights. In each luminaire were four light sources of type $36 \mathrm{~W} / 840$. In this classroom were in the whole lighting system four non-functioning sources.

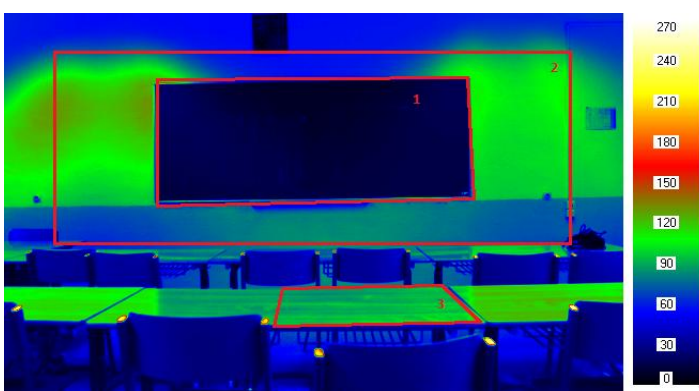

Fig.2. Classroom 2 - luminance map - representation of regions to determine the luminance

Tab 3 Measured values for classroom 2

\begin{tabular}{|l|c|c|c|c|}
\cline { 2 - 5 } \multicolumn{1}{c|}{} & $\begin{array}{c}\text { Luminance } \\
\mathrm{L}\left(\mathrm{cd} / \mathrm{m}^{2}\right)\end{array}$ & $\begin{array}{c}\text { Normal } \\
\text { illuminance } \\
\mathrm{E}(\mathrm{Ix})\end{array}$ & $\begin{array}{c}\text { Reflectivity } \\
\rho(-)\end{array}$ & $\begin{array}{c}\text { Uniformity } \\
\mathrm{U}_{0}(-)\end{array}$ \\
\hline Desk & 116,9 & 782,0 & 0,47 & 0,81 \\
\hline Blackboard & 15,5 & 318,2 & 0,15 & 0,63 \\
\hline $\begin{array}{l}\text { Paper/ } \\
\text { Notebook }\end{array}$ & 199,4 & 822,5 & 0,76 & 0,92 \\
\hline Wall & 98,5 & 374,3 & 0,83 & 0,86 \\
\hline
\end{tabular}

The luminance map in Fig. 2 illustrates that during the installation of surface-mounted luminaire only in two rows, there is an insufficient illuminance of middle part of the board. Measured values of illuminance in the central part of the board ranged around an average value of $250 \mathrm{Ix}$, while at the edges of the board was on the right side illuminance of $305 \mathrm{Ix}$ (two sources were not working closest to the board) and the left side of 350 lux, but a request for the lighting uniformity was fulfilled. These values do not match the required amount of illumination 500lx, given in norm CSN EN 12464 - 1. Conversely bench illuminance is higher than the standard requires. Standard requirement for illuminance of benches and places of visual tasks is 300lx, measured illuminance was $782 \mathrm{Ix}$. Within the sites of visual tasks we can compare two sites, paper/notebook and chalkboard. The luminance level on the blackboard was 15.5 cd.m-2 and on paper/workbook was $199.4 \mathrm{~cd} . \mathrm{m}-2$, when comparing the luminance value of workbook is roughly 13 times larger than the luminance of the board. When compared to classroom 1, the measured values are comparable

\section{Classroom 3}

This classroom was called gradational - individual rows of benches were of different heights. In this classroom was a wooden blackboard, which was lighted by three symmetrical lights. Lighting system above the benches is composed of eight surface-mounted fixtures with opal cover. In one luminaire should be four light sources of type T8. The age system can not be determined, some lamps were no longer functional. Above the board were three additional lights with aluminum grid. The luminaires are equipped with sources $3 \times 18 \mathrm{~W} / 840$.

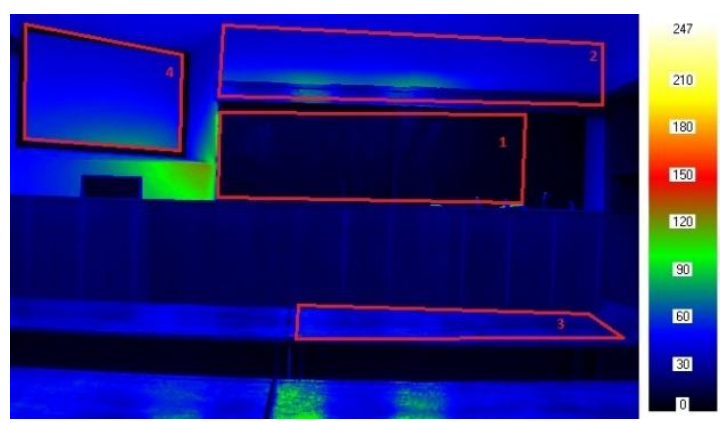

Fig.3. Classroom 3 - luminance map - representation of regions to determine the luminance 


\begin{tabular}{|l|c|c|c|c|}
\cline { 2 - 5 } \multicolumn{1}{c|}{} & $\begin{array}{c}\text { Luminance } \\
\mathrm{L}\left(\mathrm{cd} / \mathrm{m}^{2}\right)\end{array}$ & $\begin{array}{c}\text { Normal } \\
\text { illuminance } \\
\mathrm{E}(\mathrm{Ix})\end{array}$ & $\begin{array}{c}\text { Reflectivity } \\
\rho(-)\end{array}$ & $\begin{array}{c}\text { Uniformity } \\
\mathrm{U}_{0}(-)\end{array}$ \\
\hline Desk & 57,6 & 761,0 & 0,24 & 0,66 \\
\hline Blackboard & 12,2 & 580,5 & 0,07 & 0,73 \\
\hline $\begin{array}{l}\text { Paper/ } \\
\text { notebook }\end{array}$ & 177,7 & 838,5 & 0,67 & 0,92 \\
\hline $\begin{array}{l}\text { Projector } \\
\text { spot }\end{array}$ & 50,3 & 219,4 & 0,72 & 0,79 \\
\hline Wall & 57,4 & 253,9 & 0,71 & 0,81 \\
\hline
\end{tabular}

In classroom 3 were evaluated three sites of visual tasks, workbook, board, and projection space. The lighting system in the classroom 3 was given two types of surfacemounted lights, symmetrical lights with aluminum grid placed above the board, which is illuminating mostly the teacher's desk, and old lights with opal cover with a light source of type T8. Normal illuminance of board is $580.5 \mathrm{Ix}$. Benches and workbook have sufficient illuminance. Illuminance of projection space on the wall was measured only in artificial light, when illuminated by a projector, the value of the illuminance levels would increase and therefore it would increase the luminance. Using a projector leads to shutdown of the total lighting system of classroom or additional fixtures and might also cause a lack of illumination of desks - workbook. Comparing the luminance value of a workbook (177.7 cd.m-2) and boards (12.2 cd.m2) as a working place, it was found that luminance of the board is 15 times smaller than the luminance of the workbook.

\section{Classroom 4}

This classroom was the newest, it is a computer classroom with a fixed (white) board. The lighting system was new (used for about 2 years, consisted of 9 pieces of fitted lights with aluminum grid and two sources of type OSRAM 54W/840 HO Luminux, COOL WHITE. The board was lighted by two asymmetric luminaires without grid. In the light is one source of type OSRAM $36 \mathrm{~W} / 840 \mathrm{HO}$ Luminux, COOL WHITE. Lighting system, consisting of lights above the benches were dimmer-controled. When measuring the performance of the system was $100 \%$.

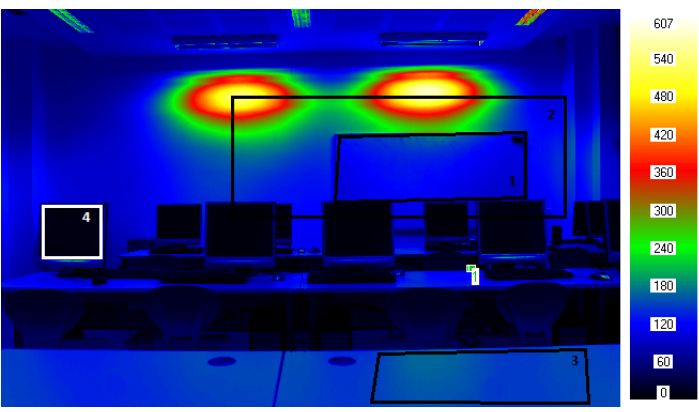

Fig.4. Classroom 4 - luminance map - representation of regions to determine the luminance

\begin{tabular}{|l|c|c|c|c|}
\cline { 2 - 5 } \multicolumn{1}{c|}{} & $\begin{array}{c}\text { Luminance } \\
\mathrm{L}\left(\mathrm{cd} / \mathrm{m}^{2}\right)\end{array}$ & $\begin{array}{c}\text { Normal } \\
\text { illuminance } \\
\mathrm{E}(\mathrm{Ix})\end{array}$ & $\begin{array}{c}\text { Reflectivity } \\
\rho(-)\end{array}$ & $\begin{array}{c}\text { Uniformity } \\
\mathrm{U}_{0}(-)\end{array}$ \\
\hline Desk & 158,5 & 725,1 & 0,70 & 0,92 \\
\hline Blackboard & 119,9 & 561,9 & 0,67 & 0,59 \\
\hline $\begin{array}{l}\text { Paper/ } \\
\text { notebook }\end{array}$ & 203,3 & 833,5 & 0,94 & 0,91 \\
\hline $\begin{array}{l}\text { Wall/ } \\
\text { projector } \\
\text { spot }\end{array}$ & 150,3 & 558,7 & 0,84 & 0,79 \\
\hline Monitor & 10,5 & - & - & - \\
\hline
\end{tabular}

In Fig. 4 is a luminance map, which shows the direction of asymmetric luminaires. The map shows that the illumination spot of fixed board was illuminated rather wall above the board. In this computer classroom was four places of visual tasks, workbook, board, projection space (part of the wall) and a monitor. The illuminance of the board and the workbook is according to CSN EN 12464-1. The luminance value of the monitor with blue screen is 10.5-cd.m-2. When working with a text editor and other common applications, the screen is mostly white, therefore the luminance of the screen will be greater. For projection on the wall the illuminance increases due to the projector and therefore the luminance also increases, depending, of course, on the projected screen and the dominant color. The last two spots are notebook and chalkboard, where the workbook was the luminance of $203.3 \mathrm{~cd} . \mathrm{m}-2$ and the board had $119.9 \mathrm{~cd} . \mathrm{m}-2$. The workbook is about 1.7 times brighter than the board. Unlike previous classrooms there is a fixed board, which is white and therefore is closer to the luminance of workbook than the green board like in previous classrooms $(1,2,3)$.

\section{Conclusion}

In the classrooms 1 and 3 are green chalkboards, but with a different surface. The difference in surface properties in this case shows the reflectance factor, which is with ceramic coating ( $\rho=0.11$ to 0.15 ), twice that of boards using wood material $(\rho=0.07)$ with a similar coating, reflectivity of the material is within the limits of conventional light reflection surfaces according to standard CSN EN 73 0580-1. For the board with fixed board the reflectance is 0.67 , that is six times greater than boards with ceramic surface, it is also due to the glossy material and white board surface. When comparing the luminance of work spaces workbook boards, it was found that luminance of conventional boards are 15 times smaller than the luminance of a workbook, but the luminance of the fixed board is only approximately 2 times smaller than of the workbook. For lighting systems in the classrooms 1 and 3 was not sufficient illuminance of the board, as required norm CSN EN 12464-1. In classroom 4 is illuminance of the board sufficient, although the asymmetrical lights illuminate mostly the wall. Uniformity in all classrooms meet the requirements of the standard. It is necessary to adjust the luminance and luminance ratios in all areas of visual tasks (workbook, board) the way that they meet standards for luminance ratios in accordance with CSN 12464-1 Z1 and also requirements of illumination, uniformity of visual tasks. Assuming the compliance of standard requirements in places of visual tasks - white workbook - whiteboard, it can be stated that the luminance ratios are in relation and hence there will be no excessive eyestrain or glare in the rapid changing of visual tasks (workbook - board). If the same classroom will be equipped with a blackboard with a reflectance of about 0.1 , it will 
reach a substantial increase in luminance - the luminance of the board will significantly decrease.

\section{ACKNOWLEDGMENT}

This article was prepared with the support of the project " Transmission of control signals in lighting systems" SP2015/182, by institution of VSB-TU Ostrava.

\section{REFERENCES}

[1] Helštýnová, B., Sokanský, K., Novák, T.: Luminance analyse of the interactive whiteboard with compare to projection screen EPE 2013, VŠB-TUO, 383-387 (2013), Czech republic, ISBN 978-80-248-2988-3

[2] Helštýnová, B., Sokanský, K., Novák, T.: Measuring the illuminance of the interior and evaluation of luminance contrast, IEEE 2014, 350-353 (2014), ISBN 978-1-4799-4661-7

[3] ČSN EN 12464-1. Světlo a osvětlení - Osvětlení pracovních prostorů - Část 1: Vnitřní pracovní prostory. Praha, 2012. 56 p.
[4] ČSN EN 12464-1 ZMĚNA Z1. Světlo a osvětlení - Osvětlení pracovních prostorů - Část 1: Vnitřní pracovní prostory. Praha, 2005. $12 \mathrm{p}$

[5] Škoda, J., Baxant P., „Luminaire photometry using digital photography”, (Fotometrie svítidel s využitím digitální fotografie)", Lightt in 2009, Proceedings of the 18th international Conference.

\footnotetext{
Autoři: Ing. Barbara Helštýnová, Republic, e-mail: barbara.helstynova@vsb.cz Ing. Tomáš Nová,k PhD.

Prof. Ing. Karel Sokanský, CSc.

Ing. Petr Bos, Vysoká škola báňská - Technická univerzita Ostrava Fakulta elektrotechniky a informatiky, 17. Listopadu 15/2172, Czech
} 